\title{
IMPROVING SPEAKING SKILL THROUGH INSIDE-OUTSIDE CIRCLE TECHNIQUE OF THE TENTH GRADE STUDENTS OF SMA N 8 DENPASAR
}

by:

\author{
I Nyoman Madra
}

\begin{abstract}
The objective of the present study is to find out whether or not speaking skill of the tenth-grade students of SMA N 8Denpasar can be improved through Inside-Outside Circle. This also helps the students to think critically about a topic. A scientific research should have an objective of study because it can make the research being useful and directed. The objective of the present study is to find out whether or not speaking skill of the tenth-grade students of SMA N 8 Denpasar can be improved through Inside-outside circle. The present study was a classroom action research (CAR) as a research design which concerns with teaching speaking through Inside-outside Circle. In the present study, the teaching and learning process was a cyclical process and divided into some cycles where each cycle consisted of some interrelated activities such as planning, action, observation, and reflection. The research instruments which were used in this study were a test (pre-test and post-test), and questionnaire. Based on the findings, the pre-existing data showed that the subjects still had low skill in English especially in speaking. The result of the pre-test showed that only 9 subjects can pass the minimum passing grade. In line with the post-test of the cycle I, the data showed that 22 subjects could pass the minimum passing grade. Finally, the post-test of cycle II showed that there were 32 subjects who passed the minimum passing grade. The increasing mean score showed that the subjects' speaking skill could be improved by implementing Inside-outside Circle.
\end{abstract}

Keywords: Speaking Skill, Inside-Outside Circle Technique.

\section{I.INTRODUCTION}

In learning English, speaking is one of the most important English language skills that should be mastered by all of the students because in learning a foreign language the final target is that to be able to use that language in this case in the real communication. But in learning English especially in speaking activities the students often find some problems. Many factors can cause the problem of the students speaking skill namely: the students' interest and motivation which is still low, the materials and the media using in teaching and learning process including the technique that is used in teaching English which is not variety. The researcher is interested in conducting this research because the researcher wants to help the students to solve their problems, especially in speaking skill.

Speaking can be categorized as a productive skill which is an effective and efficient way to transfer information from the speaker or listener in order to express their ideas. in learning speaking, the learning process must be set up as well as possible to learners' daily life and future. Speaking involves one or more participants (Harmer, 2001:1). This means 
that speaking also involves a good idea of communication. Speaking takes place everywhere and has parts of people daily activities in the good class atmosphere. Speaking is a productive skill that can be directly and observed (Brown, 2004:140). It means that the learners can directly communicate with the other people because if they mastering this skill, they can easily express and sharing their thought.

This is difficult to predict when people consider everything that involved when speaking: ideas, what to say, language, how to use grammar, vocabulary, and pronunciation as well as listen to reacting to the person they are communicating with. In learning speaking skill, the students often feel difficult to use the foreign language because they have low motivation to practice the foreign language in daily conversation or daily social interaction. Therefore, it the teachers' duty to motivate their students so the students will be confident when they talk using a foreign language.

According to the interview' result that has been done to the English teacher, four language skills; speaking has become a problem that often faced by the students. In fact, many students of SMA N 8 Denpasar still have difficulties in learning speaking skills. This can be seen in the final scores that achieved by the students in doing speaking activities where there were only $30 \%$ of students can achieve the score minimum achievement that is 2,88. Moreover, the varying ability of the students also influences their activeness in the classroom. Most of the students are afraid to speak English in front of the other people because they have limited vocabulary and low motivation. Therefore; the teacher has a responsibility to choose the suitable approach of technique to improve the students speaking skill in order to reach the goal of teaching and learning especially in speaking. In this case, the teacher has an important role in improving the students speaking skill. However, the teacher of tenth-grade students of SMA N 8 Denpasar usually using a conventional method that makes the students passive. This method must be changed in order to involve the student's participation in the teaching-learning process.

Inside-Outside Circle is a part of the cooperative learning method that can be used to solve the students' problem. This is a Cooperative learning is part of a group of teaching-learning techniques where students interact with each other to acquire and practice the elements of a subject matter and to meet common learning goals effective strategy for the students to build their confidence and give them more time to speak. Cooperative learning is a formal way of structuring activities in a learning environment that includes a specific element intended to increase the potential for rich and deeply the participants (Machpherson, 2007:1).

The researcher wants to focus on the daily social interaction as the main topic which includes: Describing pictures. This topic gives the students the opportunity to get information from the topic given by the teacher, so students can speak English fluently through the InsideOutside Circle strategy of the tenth-grade students of SMA N 8 Denpasar. The researcher used the 2013 curriculum, based on the syllabus of the tenth-grade 
students, this research was focused on the fourth main competency such as processing, reasoning, and presenting in the form of concrete and abstract domain concerned with development of the material which has been learned in the school independently, and being able to apply the appropriate method in line with the scientific rules. In this study, the speaking skill was limited in the form of short conversation based on the situation in daily social interaction such as describing pictures. In addition, the assessment of the students' performance in front of the class was focused on three aspects: comprehension, fluency, and grammar.

The research is concerned with Improving Speaking Skill Through Inside-Outside Circle. The significance is expected to give the beneficial contribution to SMA N 8 Denpasar. The significance of the study is expected to have both theoretical and practical importance to the teaching and learning process and help students to improve their speaking skill.

Theoretically, the findings of this study are expected to give more empirical evidence to the existing research finding in improving speaking skill by using the inside-outside circle technique. Furthermore, the procedures of composing this research can become a good guidance to be used to have a better result of doing research in speaking skill.

Practically, the significance of the present study is intended as an informative feedback to the English teacher, students, and other researchers. For the English teacher, the result of the study is used to evaluate the achievement in teaching speaking and it could be the reflection for the teacher in the future in teaching speaking. The teacher can use this result to provide better planning and more efficient and effective teaching, especially in teaching speaking. The teacher also can find out the result of the study to be useful when they conduct the lesson and manage the students in speaking class. For students, they could use their own prior knowledge to understand the material and also motivate students to learn to speak. Moreover, students could be more confident to show their ideas, opinions and give information orally.

\section{DISCUSSION}

\subsection{Speaking Skill}

Richards (2008:19) states that the mastery of speaking skill in English is a priority for many second or foreign language learners. Learners often measure their success in learning a foreign language through how much they feel their speaking skill has been improved. Therefore, the teacher tries to get the best approach, method or technique that is good to improve the students' speaking skill since there are varieties of approaches, methods and techniques appear from direct approaches where the teacher focuses in creating a condition for oral interaction which is appropriate for students.

According to Thornbury (2005:1), speaking is so much part of daily life that people take for granted. The average person produces ten of thousand words a day although some people like auctioneers or politicians may produce even more than that. Teaching speaking is sometimes considered as a simple process, but the implementation, both 
teacher and students often find some difficulties. Speaking skill is the productive skill in the oral mode. It is like the other skills: it is more complicated than it seems at first and involves more than just pronouncing words. In order to avoid the problems, it is important for the teacher to use various techniques in teaching speaking.

There are some reasons why speaking skill is difficult for students. First of all, they are lack of motivation in learning English and they are afraid of making mistakes when they try to speak English. Furthermore, another recent is caused by the inappropriate technique used by the teacher in teaching speaking skill. Teaching English as the foreign language requires the use of effective learning methods, techniques, language games, or activities that promote the speaking skill. Besides, there is a worry about speaking badly and therefore losing face in front of their classmates (Harmer, 2001:345). In such a situation, the teachers must pay more attention to the students who need encouragement and support in speaking activities.

According to Brown (2004:140), speaking is a productive skill that can be directly and empirically observed; those observations are invariably colored by the accuracy and effectiveness of the testtakers' speaking skill, which necessarily compromises the reliability and validity of an oral production test. Moreover, Brown divides speaking skill into two, namely: micro and macro skills of speaking. The micro skills refer to producing the smaller chunks of language such as phonemes, morphemes, words, collection, and phrasal units. The macro skills imply the speaker's focus on the larger elements: fluency, discourse, function, style, cohesion, nonverbal communication and strategic options.

Speaking is the active uses of language that make on learners of language in term of sharing meaning. In other words, speaking is the active use of language to express meaning so that other people can make sense to interact with each other (Cameron. 2001:40). To construct understanding in a foreign language, learners, would use their existing language resources, build from previous experience of language use. They speak in the foreign language in order to share understandings with other people requires attention to precise detail of the language. A speaker needs to find the most appropriate words and correct grammar to convey meaning accurately and precisely and needs to organize the course so that the listener can understand. Speaking activities, because they are source demanding to require the careful and plentiful support of various types, not just support for understanding but also support for production.

Speaking is one of the most difficult skills for students to master (Pollard 2008:33). It is difficult when learners have to consider and think about their ideas, what they are going to say, language, grammar, vocabulary, and pronunciation in one time and how to react with a person who communicates with them. Most of the students think that speaking is more difficult than the other English basic skills such as reading, writing, and listening. It is always a big issue, but what often happens is students feel more anxious related to their oral production skill. Therefore, the teacher should give the students more 
opportunities speaking and create the interesting environment and motivate the students to be more confident to convey something. The teacher also should give attention that will help the students achieve a success in speaking activities.

Speaking also has several important functions that are stated by Richards (2008:22) that there are three functions of speaking. First, speaking is used for interaction with someone. When people meet, they exchange and engage small talk because they wish to be friendly and to establish a comfortable zone of interaction with other. Second speaking is transaction refers to situations where the focus is on what is said. The third is speaking that can usefully be distinguished or speaking as performance. This refers to public speaking that transmits information before an audience, such as classroom presentations, public announcement, and speeches.

Based on those several expert statements, it can be concluded that speaking skill is the most important and difficult to learn because it is a productive skill. It is considered as an important aspect of communication to express and convey the ideas, meaning, information and one's thoughts in spoken language. Therefore, speaking skill should be taught to the students since they entered elementary school. The teacher also has to emphasize on elements that construct speaking to make clear understanding to students.

\subsection{Inside-Outside Circle}

Inside-outside circle in two concentric circles to practice asking open and close question and to reflect on what they find out as a result and this technique was developed by Dr. Spencer Kagan, this technique can give change to all students to improve their speaking skill and can help the students to practice their speaking skill and share their idea, opinion, and information together and the same time. In this part, the discussion will be related the step in the implementation of the inside-outside circle. According to Kagan (2009:27) explain the steps in implementing the inside-outside circle as the following:

1. Teachers provide the conversation situation, states the duration of conversation and provides thinking time.

2. Students from pairs. One student in each pair moves to make one large circle in the class facing outward and the other students from a large circle facing in.

3. Students find and face their partner in which the students now stand in two concentric circles.

4. Inside-outside circle students ask a question for the situation given by the teacher and the outside circle students give responses or answer to inside circle students question.

5. Teacher asks the outside circle students to move in counterclockwise and do conversation until they meet their partner before.

6. In the end, they explain or retell the information they get during the conversation.

Inside-outside circle technique is the technique which can help the students practice their speaking skill and share the information together sometime. The technique can be successfully applying if 
the teacher followed the instruction above. To make students ready for what they will talk, the teacher show prepares the topic before the subject start to play. From the textbook used for tenth-grade students of SMA N 8 Denpasar.

\subsection{Assessing Speaking}

According to Brown (2004:3) test is the method if measuring a person's ability, knowledge, of performance in a given domain. It means that test plays a role as a guide to reinforce teacher's priorities and help the students to identify what activities, knowledge, and understanding are centrally important to their progress assessment of the students should be explicitly linked to the learning processes and outcomes of their degrees programs.

Moreover, Harmer (2001:100) states that the teacher gives the students the assessment of how well they have done whether during a drill or often a longer language production exercise. Assessment is the way the teacher assesses the students on the type of activity the students are taking part in and the purpose of the assessment is to know the subject progress after being taught by using inside-outside circle technique. Luoma (2004:29) states the purpose of the test and the practical circumstances in which it will arrange general guidelines, but the most important factor when designing task is the construct-related information that the scores must deliver, or in order words what the score users need to about the examinees' speaking.

Brown (2004:172) states the component of oral proficiency scoring categories are grammar, comprehension, and fluency. In addition, the teachers usually score the students' speaking performance by using a rubric. The material should always determine the types of questions, which are constructed. Specific material may lend themselves to multiple choice-items, true or false, matching items or open-ended questions.

According to Thornbury (2003:125), there are two main ways of assessing speaking. There are holistic and analytic scoring. Holistic scoring is scoring by giving a single score of an overall impression and it has the advantage of being quicker and probably adequate of internal progress. Analytic scoring is scoring in which giving a separated score for different aspects of the task. It takes a longer time to be scored but the subject to take a lot of variety of scored. The analytic score is fair and reliable.

Richard (2008:31) states that group formation is an important factor in creating a positive interdependence. Factors involved in setting up group include: deciding with the size of the group, assigning students to groups and students roles in the group. In deciding the group size, it will depend on the task they have to carry out, the age of learners, and the time limitation for the lesson. For any activity which is used in class, whether it is the one that seeks to develop proficiency in using talk as interaction, transaction, or performance successful completion of the activity involves.

Related this study, the researcher only takes three components to assess the speaking skill of the subject under study because according to Brown (2004:12), the students speaking levels are responsive to basic speaking. The researcher will be better assessed the subject in three criteria, there are grammar, comprehension, and 
fluency. Those can be explained briefly as follows;

1. Grammar

Grammar is also a very important aspect of speaking which should be measured and assessed in language. Grammar rules should be studied in order to certainly help students to speak more accurately and acceptable by paying attention to grammar.

2. Comprehension

It refers to the students' wellness expression and understanding of the conversation and the content is clear. The scope is very limited language experience; the speaker can understand simple questions and statements if it is delivered slowly. In addition, the students comprehend the whole conversation without any repetition.

3. Fluency

Fluency refers to the speaker ability to continue speech without too much hesitation there is no doubt and stop because of limited language use.

In conclusion, in relation with this study, the speaking skill is measured after the researcher applied the inside-outside circle technique in teaching activities. The students' speaking assessment will be scored based on the basic speaking categories such as grammar, comprehension, and fluency. The test that is used by the researcher in this study is a monologue performance test. The test will be constructed by the choosing the picture related to the material and students have to describe the picture in front of the class by using appropriate spoken language.

\subsection{Empirical Review}

Considering the importance of speaking skill for a language education success, many researchers had conducted studies about improving speaking skill through the inside-outside circle. However, in this part, the researcher described two empirical review explanation about researchers which were to related to the present study. There are briefly empirically reviewed as follows:

The strengths of Inside-Outside Circle Technique is this technique can make the students get different information at the same time on the material being taught and the techniques can make students easier and fun in learning English with their friends and this technique also can make the students improve vocabulary and review the vocabulary terms.

The weaknesses of the InsideOutside Circle Technique as nothing perfect in the world so does the technique. This technique has its own weaknesses, like this technique requires a large classroom so that it is difficult to apply if the classrooms are too small and this technique is also complicated to do when the classrooms are too small and the last this technique is too long to do, so that the students become distracted in remembering the information which they have gotten from their friends.

The first similar research was conducted by Noviantari (2016) in her thesis entitled "Improving Speaking Skill Through Inside-outside Circle Technique of the Eighth Grade Students in SMPN 2 Kuta". The result of her study showed 
that the effectiveness of implementation of the inside-outside circle can improve student's ability of the eight grades of SMPN 2 Kuta. In this study, the researcher asked the students to make a short conversation based on the situation given. Their performance was assessed by using a scoring rubric: fluency, comprehension, and grammar.

The second researcher was conducted by Dewi (2016) in her thesis "Improving Speaking Skill of the eighthgrade students of SMPN 9 Denpasar through Inside-outside Circle". The result of the data analysis of cycle I and cycle II clearly figured out the increasing mean figures respectively. Besides, the result of the analysis of the question is clearly showing the comparative percentage of positive response towards to implementation of the inside-outside circle in improving the subjects' speaking skill.

\subsection{Research Design}

The present study is a classroom action research (CAR) as a research design which concerns with teaching speaking through Inside-outside Circle. Pelton (2010:3) states that action research in the school is a systematic approach to improve teaching practices. It is a simple process and if you learn how to use it, it will meet many of your teaching goals. In relation to this study, classroom action research will be a concern to improve speaking skill of the subjects under study through Inside-outside Circle by using two kinds of tests namely: initial reflection (IR) or pre-test and reflection (R) or posttest.

Initial reflection $(\mathbb{R})$ is intended to evaluate the pre-existing the students'speaking skill while reflection (R) administered at the end of each session it means to reveal the expected improvement in the students' speaking achievement after conducting teaching and learning process through Insideoutside Circle.

this classroom action study, the teaching and learning processes were divided into two cycles in which each cycle consists of two sessions. Each session consists of four interconnected activities, namely: planning (P), action (A), observation $(\mathrm{O})$, and reflection $(\mathrm{R})$.

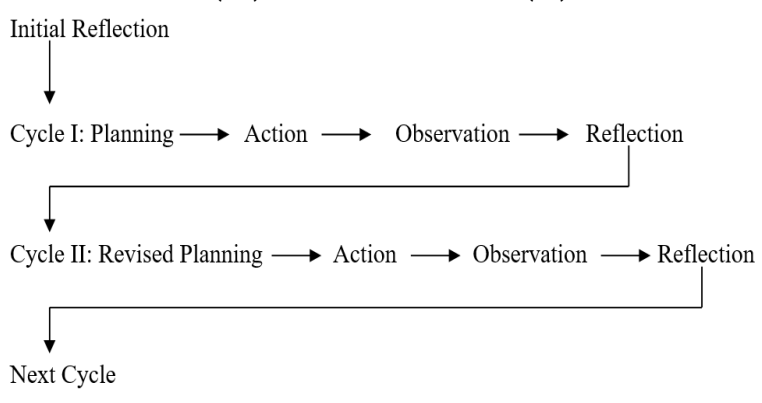

\subsection{Research Procedure}

This study was aimed to improve speaking skill of the tenth-grade students of SMA N 8 Denpasar by using Insideoutside Circle technique. In the present study, the teaching and learning process was a cyclical process and divided into some cycles where each cycle consisted of some interrelated activities such as planning, action, observation, and reflection. Initial reflection was firstly carried out.

\subsection{Initial Reflection}

Initial reflection of a classroom action research was conducted by the researcher in order to know the problem occurred in the classroom. Based on the brainstorming and observation, the researcher found that the tenth-grade students of X IPA5 still had a problem 
with speaking skill. Initial reflect was implemented at the beginning of the research. The initial reflection consists of pre-test which was intended to evaluate students of the subject. The mean score of the initial reflection was compared to the corresponding mean score of the reflection administered at the end of each session. That is to know the students' result improvement in speaking skill during the research.

\subsection{Finding}

The present study was intended to overcome the problems that were faced by the subjects in learning English especially speaking. Based on the initial condition of the subjects, it was found that they had low achievement in speaking. They found difficulty to speak because they were not really confident. Therefore, this study was designed as a classroom action research because the purpose was to solve the problems of the subjects. In addition, to improve the subjects' speaking skill, the researcher implemented Inside-outside circle technique. Besides, this study was focused on speaking particularly about language expression.

In conducting the study, the researcher has interviewed the English teacher to know the class that had problems in English, especially in speaking skill. After interviewing the English teacher, the researcher decided to conduct this research to the tenth-grade students especially the students of IPA 5. Based on the interview with the English teacher, the tenth grade students of IPA 5 were low in speaking skill. They were afraid to make mistake when they spoke, and they had low ability in speaking especially fluency, comprehension, and grammar. Therefore, the researcher conducted the inside-outside circle technique to solve the problem.

Furthermore, to get the valid and reliable data, the researcher administered the research instruments. There were two kinds of instruments that were used in the present study; they were test and questionnaire. In addition, the test was divided into two tests; they were pre-test and post-test. There were two post-tests which were administered in this study; they were administered in cycle I and cycle II. The questionnaire was given at the end of cycle II. Moreover, administering the instrument was intended to answer the research problem and to prove whether or not the implementation of the technique can improve the subjects' speaking skill in expressing intention and congratulating others.

To collect the data, the researcher administered tests and scored it by using a rubric. There were two tests that were administered by the researcher to collect the data. They were pre-test, post-test 1 and post-test 2. The pre-test was administered to know the subjects' preexisting speaking skill before the researcher does the action of the research. It also used to know how the students responding to the teaching-learning process in the class and how the teacher leads the students in teaching learning process. Besides, the researcher administered the post-test in every cycle to measure the improvement of the subjects' speaking skill after implementing the inside-outside circle technique. In addition, there were two post-tests administered; they were post- 
test in cycle I and cycle II. Therefore, there were three sets of data of the pre-test, posttest I and post-test 2 that were obtained and tabulated. They showed the subjects' improvement score in speaking skill.

\subsection{Discussion}

This study used classroom action research. It was intended to improve speaking skill of the tenth-grade students of SMA N 8 Denpasar. The research was started by conducting a pre-cycle at the very beginning. Furthermore, there were two cycles that were done in the present study; they were cycling I and cycle II. Each cycle had two sessions, each session took 80 minutes. In addition, the cycles were used to collect the data to know the improvement of the subjects after implementing the inside-outside circle technique.

In pre-cycle, the researcher interviewed the English teacher of SMAN 8 Denpasar who taught the class which was used in this study. The result of the interview showed that the subjects still had several problems in speaking skill. The result of the data analysis also showed low speaking skill. The mean score of the pre-test was 64.66. There were only 9 of the subjects pass the minimum passing grade. The researcher found that subjects' weakness was in speaking especially in fluency, comprehension, and grammar. The researcher interviewed the English teacher of SMA N 8 Denpasar and found that the subjects' problem in learning English. On the other hand, confidence and motivation became problems besides fluency, comprehension, and grammar when the research was conducted at the pre-cycle. The researcher had to make an effective planning for the research to improve the subjects' speaking skill. After doing some preparation, the researcher conducted cycle I.

In cycle I, the researcher taught the subjects by using the think-pair-share technique. Based on the data analysis after administering post-test at the end of the cycle I, inside-outside circle technique helped the subjects to improve their speaking skill. The data showed the subjects' improvement in post-post which was 76.24 . There were 22 of 38 subjects who passed the minimum passing grade. In the first session, there were only a few subjects who were active in asking the questions, and they still talked with their friends. However, in the second session, the subjects were more active than in the first session. In addition, there was an improvement in the subjects' speaking skill. Moreover, the implementation of inside-outside circle technique showed the improvement of the subjects' in speaking skill during teaching and learning process. The success indicator was not yet achieved. The subjects still had difficulties in fluency and confidence to speak in front of others. Therefore, to get a better result, the researcher revised the planning for the next cycle. Then the researcher conducted cycle II.

In cycle II, the researcher made some revisions in teaching and learning process. The researcher reconstructed the planning to achieve a higher result in action. The result of cycle II also showed that the subjects' skill in speaking could be improved through inside-outside circle technique. The mean score also showed an improvement from the subjects. In the third and fourth session, the subjects were more active in asking the questions, and 
also they were enthusiastic during the teaching-learning process. This cycle also showed the subjects' improvement which can be seen from the subjects' performance. The mean score of the subjects improved if it was compared with the pre-test and post-test 1 of cycle I. In this cycle, there were 32 of 38 subjects who passed minimum passing grade. Consequently, the present classroom action research could be ended.

In addition, the data of the questionnaire stated that most of the subjects gave positive responses about the implementation of inside-outside circle technique in improving the subjects' speaking skill. The data showed that more than $94 \%$ of the responses were agreed on the implementation of the inside-outside circle in improving the subjects' speaking skill. As the result, most of the subjects were agreed with the implementation of inside-outside circle technique in teaching learning process. Moreover, the technique was acceptable in the class. During the process of speaking, the implementation of the technique built and created a good atmosphere. It affected the subjects' feeling in learning speaking. It was really helpful for them because it motivated them to develop their ideas that appeared in their mind and it helped them to create confident and critical thinking because they can compare their teaching with their friends

Based on the findings of the present classroom action research it showed that the subjects' speaking skill improved. Moreover, inside-outside circle technique was effective to be implemented in teaching speaking especially in fluency, comprehension, and grammar. Therefore, it can be concluded that inside-outside circle technique could improve speaking skill of the tenth-grade students of SMA N 8 Denpasar.

\section{CONCLUSION}

It had been stated previously that the objective of conducting this research was to improve speaking skill of the tenthgrade students of SMA N 8 Denpasar especially $X$ IPA 5 by implementing Inside-Outside Circle technique. There were two cycles conducted by the researcher, in which each cycle consisted of two sessions and the end of each cycle there was a post-test administered to the students. The purpose of giving the posttest was to know the data of the students' improvement after the implementation of the Inside-Outside Circle technique that was conducted in each cycle of the present study.

Based on the findings, the preexisting data showed that the subjects still had low skill in English especially in speaking. The result of the pre-test showed that only 9 subjects can pass the minimum passing grade. In line with the post-test of the cycle I, the data showed that 22 subjects could pass the minimum passing grade. Finally, the post-test of cycle II showed that there were 32 subjects who passed the minimum passing grade. The increasing mean score showed that the subjects' speaking skill could be improved by implementing Insideoutside Circle.

In addition, there was supporting data that were taken by administering the questionnaire. The results of it showed that more than $92 \%$ of the subjects agreed toward the implementation of insideoutside circle technique in teaching speaking. The figures showed that most of 
the subjects gave positive responses to the technique used. Besides, the technique was effective to be implemented in teaching and learning process especially in teaching speaking.

Based on the findings, the present classroom action research showed that the subjects' speaking skill was improved. Inside-Outside Circle technique gave students the opportunity to express themselves more so they were not shy when they spoke in front of the class. Therefore, it can be concluded that speaking skill of the tenth-grade students of SMA N 8 Denpasar could be improved through inside-outside circle technique.

In the present classroom action research, the researcher implemented inside-outside circle technique to improve speaking skill. This research was conducted at the tenth-grade students of SMA N 8 Denpasar. This research has two cycles which consisted of two sessions of each cycle. The researcher would like to recommend some constructive suggestions to the English teacher, the tenth-grade students, and the other researchers.

Especially the teacher of the tenth-grade students in SMA N 8 Denpasar are suggested to use the insideoutside circle as an alternative technique in teaching English speaking since it can build up students' interest and motivation in learning speaking skill. This technique also could make the subjects enjoy the teaching-learning process. The English teacher also must be able to manage the class and create a good atmosphere for the learning process. Moreover, the researcher also recommends the English teacher to combine this technique with another and strategy, which can greatly increase the motivation of the students. Therefore, the inside-outside circle can be one of the alternative techniques to help the teacher teach speaking more effectively in the classroom.

The tenth-grade students, especially students the X IPA 5 of SMA N 8 Denpasar are suggested to be ready in communicating by using English because learning English without practicing is nothing. The researcher also suggests the subjects should not be afraid to speak English and be confident when speaking in front of the class. They should practice their speaking skill not only in the school but also in their environment. It is suggested that the students develop their speaking skill by using an inside-outside circle because this technique is able to build students' interest and motivation in learning speaking. They should motivate and encourage themselves to be more confident in saying their opinions, ideas and feelings and many others in a variety of language. Besides, the students should develop their ideas more and can also build their confidence.

Moreover, the other researchers are also suggested to implement insideoutside circle technique in teaching speaking because this technique could improve students' speaking skill by giving them more opportunity to sharing their taught and even build their confidence. Thus, the researcher suggests the other researchers find a more interesting topic to create a good atmosphere in teaching learning process while implementing this technique. Moreover, the result of this study can be used as a reference to conduct further research that is related to the 
implementation of a think pair share technique.

\section{References}

Brown, Douglas. 2004. Language assessment Principles and Classroom Practices. San Francisco: Longman.

Cameron, Lynne. 2001. Teaching Language to Young Learners. New York: Cambridge University Press.

Harmer, Jeremy. 2001. The Practice of English Language Teaching, 3rd Ed. New York: Pearson Education Limited.
Kagan, S., Kagan, M. 2009. Cooperative Learning. San Clemente: Kagan Publishing.

Pelton, Robert P (Ed.). 2010. Action Research For Teacher Candidates: Using Classroom Data To Enhance Instruction. USA: Rowman \& Littlefield Education.

Richard, Arends I. 2008. Learning to Teach: Belajar untuk Mengajar. Yogyakarta: Pustaka Pelajar. 